\title{
KAJIAN TERHADAP PENDAPATAN MIGRAN WANITA PEDAGANG SEKTOR INFORMAL DI KOTA DENPASAR
}

\author{
Ni Nym Setya Ari Wijayanti ${ }^{1}$ \\ A.A. I N Marhaeni \\ ${ }^{1,2}$ Fakultas Ekonomi dan Bisnis Universitas Udayana (Unud), Bali, Indonesia \\ Email : setyaarry98@yahoo.co.id
}

\begin{abstract}
ABSTRAK
Penelitian ini bertujuan untuk menganalisis, pengaruh tingkat pendidikan,umur, etnis, lama usia perkawinan, jumlah tanggungan dan lama migrasi terhadap jarak migrasi pedagang migran wanita sektor informal; pengaruh tingkat pendidikan, umur, etnis, lama usia perkawinan, jumlah tanggungan, lama migrasi dan jarak migrasi terhadap tingkat pendapatan pedagang migran wanita sektor informal; peran jarak migrasi dalam memediasi pengaruh tingkat pendidikan, umur, etnis, lama usia perkawinan, jumlah tanggungan dan lama migrasi terhadap tingkat pendapatan pedagang migran wanita sektor informal di Kota Denpasar. Hasil penelitian menunjukkan bahwa tingkat pendidikan, umur dan jumlah tanggungan berpengaruh positif dan signifikan terhadap jarak migrasi pedagang migran wanita. Lama migrasi berpengaruh negatif dan signifikan terhadap jarak migrasi pedagang wanita migran. Etnis dan lama usia perkawinan tidak berpengaruh signifikan terhadap jarak migrasi pedagang wanita migran. Tingkat pendidikan, umur, etnis, jumlah tanggungan dan jarak migrasi berpengaruh positif dan signifikan terhadap pendapatan pedagang wanita migran. Lama migrasi berpengaruh negatif dan signifikan terhadap pendapatan pedagang wanita migran. Lama usia perkawinan tidak berpengaruh signifikan terhadap tingkat pendapatan wanita migran.
\end{abstract}

Kata kunci : pendapatan, jarak migrasi, sektor informal

\section{ABSTRACT}

This study aims to analyze; the influence of education level, age, ethnicity, length of marriage age, number of dependents and length of migration to distance migration of informal women migrant traders; the influence of education level, age, ethnicity, age of marriage age, number of dependents, duration of migration and distance of migration to income level of informal female migrant traders; the role of migration spacing in mediating the influence of education level, age, ethnicity, age of marriage, number of dependents and length of migration to income level of informal female migrant traders. The results showed that the level of education, age and number of dependents have a positive and significant effect on the distance of migration of informal women migrant traders in Denpasar City. The duration of migration has a negative and significant effect on the distance of women traders migration. Ethnic and longevity of marriage have no significant effect on migration distance of female migrant traders. The level of education, age, ethnicity, number of dependents and migration spacing have a positive and significant impact on the income of female migrant traders. The duration of the migration has a negative and significant effect on the merchant's income. The age of marriage has no significant effect on income level.

Keywords: income, migration distance, informal sector. 


\section{PENDAHULUAN}

Migrasi penduduk merupakan bagian integral dari proses pembangunan secara keseluruhan (Tjiptoherijanto, 2000; Skeldon, 2008; De Haas, 2010a). Migrasi telah menjadi penerima dan penyebab dampak dari adanya perubahan struktur ekonomi dan struktur sosial suatu daerah. Pembangunan tetap dipandang sebagai dasar kekuatan yang menggerakkan migrasi sampai saat ini, dengan melihat fakta bahwa adanya kenaikan migrasi keluar nasional yang meningkat akibat terjadinya pertumbuhan ekonomi modern di Eropa, pada awalnya bertahap, mencapai puncaknya, dan kemudian menurun (Chiswick dan Hatton, 2003).

Masyarakat melakukan migrasi cenderung disebabkan oleh motif ekonomi. Hal ini mencerminkan para migran telah mempertimbangkan berbagai keuntungan dan kerugian yang akan didapatnya sebelum migran tersebut memutuskan untuk melakukan migrasi ataupun tetap tinggal di tempat asalnya (Tjiptoherijanto, 2000). Seseorang melakukan migrasi disesabkan oleh Kondisi ekonomi dan sosial di daerah asal yang tidak memungkinkan untuk terpenuhi. Tingkat kebutuhan individu berbedabeda, maka pandangan terhadap daerah asal dari individu berbeda-beda pada masyarakat tersebut, sehingga setiap individu dalam mengambil keputusan untuk melakukan mobilitas akan berbeda pula (Mantra, 1992). Menurut Simmons (1986), seperti dikutip Keban (1994) faktor latar belakang struktural dan manfaat daerah tujuan maupun latar belakang individu mempengaruhi keputusan seorang dalam mengambil sebuah keputusan. 
Transformasi struktur ketenagakerjaan yang unbalance merupakan penyangga dari sektor informal (Ramarao, 2015). Cara pandang masyarakat terhadap sektor informal mulai berubah ketika sektor informal bisa memberikan kontribusi yang berarti, baik dalam kapasitas outputnya maupun penyangga tenaga kerja (Lokhande, 2011). Sektor informal menjadi alternatif yang komplementer terhadap sektor formal bukan lagi hanya sebagai tempat penampungan.

Semakin berkembangnya sektor - sektor informal di daerah perkotaan menyebabkan banyak penduduk - penduduk desa maupun luar daerah datang berbondong - bondong ke daerah perkotaan yang memungkinkan mereka untuk terjun ke sektor informal ini (Indrawati, 2009). Para pendatang beranggapan bahwa mereka akan mampu terjun ke sektor informal tersebut karena dalam sektor informal tidak diperlukan adanya keterampilan khusus untuk dapat memasuki sektor tersebut. Penurunan pada sektor pertanian menyebabkan masyarakat desa tertarik untuk bermigrasi ke kota dengan harapan memperbaiki kehidupan mereka karena kesulitan perekonomian dalam mempertahankan hidup (Lily, 2006) . Pendapatan yang tidak mencukupi sedangkan semakin tingginya biaya hidup menjadi salah satu alasan. Namun rendahnya latar belakang pendidikan para migran tertarik untuk bekerja di sektor informal karena di sektor informal memerlukan skill dan mereka tidak mampu bersaing pada sektor tersebut (Gugler, 1989).

Sektor perdagangan adalah salah satu sektor yang menonjol dalam menyerap pekerja di Kota Denpasar. Persentase tenaga kerja yang diserap oleh sektor perdagangan cukup besar yang mencapai 30 persen dari semua sektor yang ada. 
Menurut Boserup (1984) bagi seorang perempuan yang telah berkeluarga kegiatan berrdagangan di pasar umum merupakan salah satu pekerjaan utama. Dari perkembangan tersebut, wanita dianggap lebih tepat untuk bekerja di sektor informal karena dalam sektor informal pekerjaan memungkinkan seorang wanita untuk mempersiapkan masakan di dapur dan mengasuh anak sambil (Forsman and Temel, 2011). Keterlibatan perempuan di bidang ekonomi akan meningkatkan posisi ekonomi perempuan, sehingga mereka percaya status dan kedudukan perempuan akan meningkat di masyarakat (Marhaeni, 2008).

Berdasarkan status pekerjaan, wanita di Bali yang bekerja pada sektor publik seluruhnya. Terserap kedalam dua sektor yakni sebagai tenaga kerja di sektor formal dan sektor informal (BPS, 2008). Tenaga kerja yang termasuk kedalam kategori tenaga kerja di sektor informal adalah tenaga kerja yang berpenghasilan tidak tetap atau jenis pekerjaan yang relatif mudah untuk dikerjakan karena tidak memerlukan persyaratan yang ketat (Subair, 2011).

\section{Gambar 1}

\section{Distribusi Perempuan 15 Tahun ke atas yang Bekerja Menurut Status} Pekerjaan di Kota Denpasar Tahun 2015

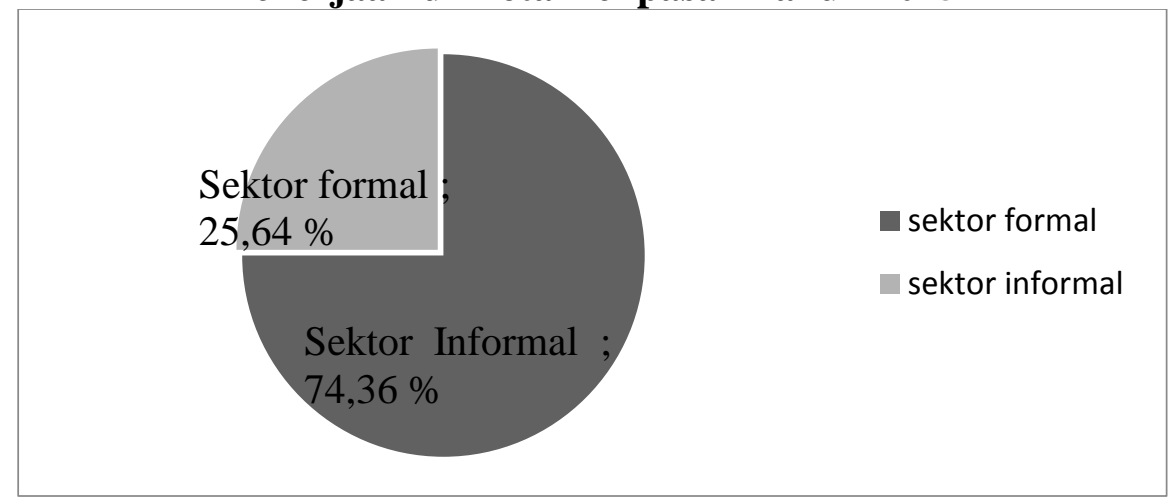

Sumber : BPS Provinsi Bali,2015 (data diolah) 
Perpindahan tenaga kerja dalam sektor informal pada dasarnya cukup tinggi, karena terdapat hubungan kontrak dalam jangka panjang. Hal ini yang mengakibatkan angkatan kerja cukup mudah memasuki sektor ini sehingga diharapkan bisa bertindak sebagai sebuah kekuatan penyangga antara kesempatan kerja ataupun pengangguran. Seperti yang dibuat pada Gambar 1, sebanyak 74,36 persen perempuan bekerja di atas 15 tahun terserap ke dalam sektor informal, dan sisanya sebesar 25,64 persen bekerja pada sektor formal.

Mengingat bahwa migran sektor informal sebagian besar terserap dan bergantung pada sektor ini, maka sangat penting untuk mengetahui hal- hal yang mempengaruhi tingkat pendapatan migran wanita yang bekerja sebagai pedagang pada sektor informal di Kota Denpasar.

\section{METODE PENELITIAN}

Metode penelitian dalam penelitian ini adalah metode kuantitatif, menggunakan data primer yang diperoleh dari responden dengan kuisioner. Populasi sebanyak 2.998 orang pedagang di Kota Denpasar. Teknik penentuan sampel menggunakan stratified random sampling. Tingkat eror sebesar $10 \%$ yang dihitung dengan menggunakan rumus slovin yang memperoleh sampel yang akan diteliti berjumlah 97 yang dalam penelitian ini digunakan 100 sampel.

Variabel dependen (dependent variable) dalam penelitian ini adalah variabel pendapatan wanita migran di sektor informal, Variabel independen (independent variable) dalam penelitian ini adalah tingkat pendidikan, umur, lama usia perkawinan, etnis, jumlah tanggungan keluarga dan lama bermigrasi. Dalam 
penelitian ini juga terdapat sebuah variabel intervening yaitu jarak migrasi. Definisi operasional variabel yang digunakan sebagai berikut :

1) Pendapatan tenaga kerja wanita informal (Y1) adalah hasil dari setiap pekerjaan yang dilakukan yang diukur dengan satuan rupiah.

2) Jarak migrasi $\left(\mathrm{Y}_{2}\right)$ adalah jarak dari daerah asal ke daerah tujuan baik itu dari provinsi luar ke Kota Denpasar termasuk dari kabupaten yang ada di Provinsi Bali ke Kota Denpasar yang diukur dengan satuan kilometer.

3) Tingkat pendidikan $\left(\mathrm{X}_{1}\right)$ adalah jumlah tahun sukses responden dalam menamatkan tingkat pendidikan formal yang diukur dengan satuan tahun.

4) Umur $\left(\mathrm{X}_{2}\right)$ adalah lama hidup seseorang sejak lahir sampai dengan penelitian ini dilakukan yang diukur dalam satuan tahun. Dalam variabel ini umur dimasukkan untuk usia tenaga kerja informal saat melakukan kegiatan informal dihitung dari ulang tahun terakhir yang diukur dengan satuan tahun.

5) Lama usia perkawinan $\left(X_{3}\right)$ adalah lamanya seorang reponden menjalani kehidupan perkawinan yang berkemungkinan mempengaruhi seorang untuk ikut serta dalam dunia kerja yang diukur dengan satuan tahun.

6) Etnis $\left(\mathrm{X}_{4}\right)$ adalah suatu kesatuan sosial yang dapat dibedakan dari kesatuan yang lain. Etnis dibagi menjadi 2 Bali dan non Bali, untuk etnis bali (D1) dan non Bali (D0) (dummy).

7) Jumlah tanggungan keluarga $\left(\mathrm{X}_{5}\right)$ adalah banyaknya anggota rumah tangga yang menjadi tanggungan pekerja perempuan baik itu orang tua/dewasa dan atau anak - anak yang diukur dengan satuan jiwa. 
8) Lama bermigrasi $\left(\mathrm{X}_{6}\right)$ adalah lamanya seseorang melakukan migrasi yang diukur dalam satuan tahun yang diukur dengan satuan tahun.

Model dapat dilihat pada Gambar 2.

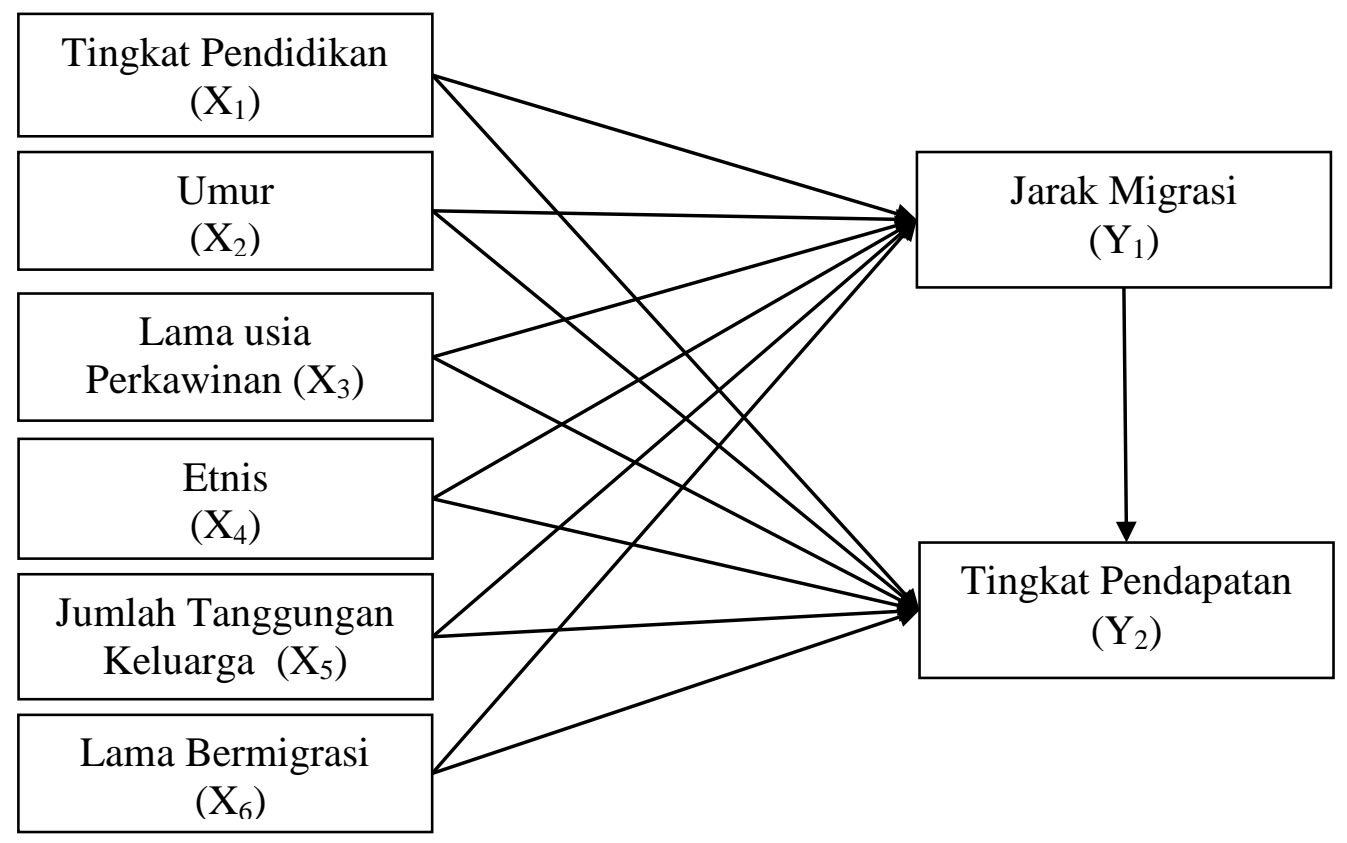

Gambar 2

Kerangka Konsep Penelitian

\section{TEKNIK ANALISIS DATA}

1) Analisis SWOT

Analisis SWOT adalah sebuah instrumen perencanaan strategis digunakan untuk mengevaluasi Strength, Weakness, Opportunity dan Threat yang terdapat dalam sektor informal yang berkembang di Kota Denpasar. Proses ini melibatkan penentuan tujuan yang spesifik dari spekulasi sektor informal dan 
menidentifikasi faktor internal dan eksternal yang mendukung dan yang tidak dalam mencapai tujuan.

2) Analisis Deskriptif

Statistik deskriptif digunakan untuk membantu menggambarkan keadaaan (fakta) yang sebenarnya dari suatu penelitian. Analisis ini berkaitan dengan metode - metode pengumpulan dan penyajian data sehingga memberikan informasi yang berguna .

2) Analisis Jalur (Path Analysis)

Analisis jalur merupakan alat untuk mengetahui pengaruh langsung dan pengaruh tidak langsung dari suatu variabel, dimana beberapa variabel dianggap sebagai penyebab dari variabel lainnya, pada analisis jalur terdapat suatu variabel yang dapat berperan ganda, dimana pada satu sisi suatu variabel bisa sebagai variabel independen dalam suatu hubungan namun menjadi variabel dependen pada hubungan lain mengingat adanya hubungan kausal yang berjenjang (Suyana Utama,2010).

Persamaan struktural analisis jalur :

$Y_{1}=\beta_{1} X_{1}+\beta_{2} X_{2}+\beta_{3} X_{3}+\beta_{4} X_{4}+\beta_{5} X_{5}+\beta_{6} X_{6}+\varepsilon$

$Y_{2}=\beta_{7} X_{1}+\beta_{8} X_{2}+\beta_{9} X_{3}+\beta_{10} X_{4}+\beta_{11} X_{5}+\beta_{12} X_{6}+\beta_{13} Y_{1}+\varepsilon_{2}$

\section{HASIL PENELITIAN}

\section{Analisis SWOT}

Faktor - faktor internal yang mempengaruhi pengembangan sektor informal di Kota Denpasar adalah keahlian sumber daya manusia, modal kerja, tenaga kerja, 
teknologi, ketersediaan bahan baku, harga bahan baku, sarana prasarana, pengalaman kerja dan promosi. Faktor - faktor eksternal yang mempengaruhi pengembangan sektor informal di Kota Denpasar adalah biaya sewa, pelatihan, pemberian kredit lunak, pinjaman, kemitraan, persaingan, kondisi perekonomian yang tidak stabil, hukum, kebijaksanaan pembangunan, dan keberadaan sektor formal yang menjual jenis barang yang sama.

Setelah diketahui faktor - faktor internal dan eksternal maka dilakukan analisis SWOT. Analisis SWOT dilakukan untuk mengetahui kekuatan dan kelemahan, peluang dan ancaman. Hal ini untuk mengetahui strategi yang akan dipilih untuk mengembangkan sektor informal di Kota Denpasar.

1) Strategi Kekuatan-Peluang

Strategi ini disusun dengan menggunakan kekuatan yang dimiliki dan memanfaatkan peluang yang ada. Strategi yang dilakukan adalah: pengalaman kerja sebagai kekuatan dalam sektor informal, maka untuk mengembangkan sektor informal tersebut dengan memberikan pinjaman bagi pelaku kegiatan di sektor informal.

2) Strategi Kelemahan-Peluang

Strategi kelemahan-peluang disusun untuk mengurangi kelemahan dengan menggunakan peluang yang ada. Strategi ini dilakukan melalui penyediaan bahan baku melalui adanya kemitraan. Kemitraan ini bisa dilakukan dengan kerjasama pemerintah swasta. Kekurangan sarana prasarana yang tersedia diatasi melalui peminjaman. 
Ni Nym Setya Ari Wijayanti, dan A.A. I N Marhaeni. Kajian Terhadap Pendapatan Migran...

3) Strategi Kekuatan-Ancaman

Starategi kekuatan dan ancaman merupakan srategi yang digunakan dengan menggunakan kekuatan untuk menghindari ancaman. Pengalaman kerja dan keahlian dapat dijadikan sebagai modal untuk menghadapi persaingan dan kondisi perekonomian yang tidak stabil.

4) Strategi Kelemahan-Ancaman

Strategi ini disusun untuk meminimalkan kelemahan dan menghindari ancaman yang ada. Persaingan dengan sektor informal menjadikan sektor informal menjadi terabaikan. Hal ini mengakibatkan kondisi sarana dan prasarana pada sektor informal kurang terpenuhi. Strategi yang dilakukan adalah mengadakan promosi terhadap produk sektor informal.

\section{Evaluasi Terhadap Pemenuhan Analisis Jalur}

Dalam model analisis jalur hubungan antar variabel adalah linier dan aditif. Uji linieritas menggunakan curve fit dan menerapkan prinsip parsimony, yaitu apabila model signifikan atau non signifikan berarti dapat dikatakan model berbentuk linier.

Tabel 1

Hubungan Linier AntarVariabel Penelitian

\begin{tabular}{cccc}
\hline Hubungan Variabel & R-Square & F & Sig. \\
\hline X1 -> Y1 & 0,131 & 14,800 & 0,000 \\
X2 -> Y1 & 0,139 & 15,867 & 0,000 \\
X3 -> Y1 & 0,085 & 9,060 & 0,003 \\
X4 -> Y1 & 0,078 & 8,262 & 0,005 \\
X5 -> Y1 & 0,189 & 22,808 & 0,000 \\
X6 -> Y1 & 0,001 & 0,078 & 0,781 \\
X1 -> Y2 & 0,381 & 60,401 & 0,000 \\
X2 -> Y2 & 0,118 & 13,162 & 0,000 \\
X3 -> Y2 & 0,310 & 43,947 & 0,000
\end{tabular}




\begin{tabular}{cccc}
$\mathrm{X} 4$-> Y2 & 0,056 & 5,831 & 0,018 \\
$\mathrm{X} 5$-> Y2 & 0,305 & 43,060 & 0,000 \\
$\mathrm{X} 6$-> Y2 & 0,019 & 1,852 & 0,177 \\
$\mathrm{Y} 1$-> Y2 & 0,532 & 111,529 & 0,000 \\
\hline
\end{tabular}

Sumber : Data Penelitian,2017

Pada Table 1 bawah terdapat dua variabel yang tidak berhubungan secara linear satu dengan yang lainnya, yaitu hubungan antarvariabel X6 -> Y1 dan X6 $>$ Y2. Hasil ini ditunjukkan oleh signifikansi yang lebih besar dari 0,05. Hubungan antra variabel lainnya menunjukkan hubungan yang linear dilihat dari nilai signifikansi yang kurang dari 0,05. Hubungan yang paling linear adalah antara Y1 -> Y2, yaitu ditunjukkan oleh F-Hitung paling besar, yaitu sebesar 111,529.

\section{Evaluasi Terhadap Validitas Model}

Validitas model struktural dapat dilihat dari nilai $\mathrm{R}^{2}$ dari variabel dependen. Nilai $\mathrm{R}^{2}$ variabel dependen dalam penelitian ini disajikan pada Tabel 2. Dalam penelitian ini terdapat dua variabel dependen, yaitu jarak migrasi (Y1) dan tingkat pendapatan (Y2). Terhadap kedua variabel dependen, variabel independen memberikan nilai Y1 memberikan nilai 0,415, sedangkan variabel tingkat pendapatan (Y2) memberikan nilai 0,813 .

\section{Tabel 2}

Hasil Evaluasi Validitas Model

\begin{tabular}{cclcc}
\hline No & $\begin{array}{c}\text { Variabel } \\
\text { Dependen }\end{array}$ & Variabel & $\mathrm{R}^{2}$ & $\begin{array}{c}\text { Kemampuan } \\
\text { menjelaskan } \\
\text { Variabel Independen }\end{array}$ \\
\hline 1 & Jarak Migrasi (Y1) & $\begin{array}{l}\mathrm{X} 1, \mathrm{X} 2, \mathrm{X} 3, \\
\mathrm{X} 4, \mathrm{X} 5, \mathrm{X} 6\end{array}$ & 0,415 & Sedang
\end{tabular}


2 Pendapatan(Y2) X1, X2, X3, $0,813 \quad$ Kuat Sumber : Data Penelitian,2017.

Koefisien determinasi total persamaan struktural dari model penelitian ini dengan perhitungan sebagai berikut :

$$
\begin{aligned}
& R_{m}^{2}=1-P_{e 1}^{2} P_{e 2}^{2} \ldots \ldots . P_{e p}^{2} \\
& R_{m}^{2}=1-(0,764)^{2}(0,432)^{2} \\
& R_{m}^{2}=1-(0,583)(0,187) \\
& R_{m}^{2}=1-0,109 \\
& R_{m}^{2}=0,891
\end{aligned}
$$

Koefisien determinan total sebesar 0,891 mempunyai arti bahwa sebesar 89,1 persen variabel dari tingkat pendapatan dapat dijelaskan oleh model yang dibentuk, sedangkan sisanya sebesar 10,9 persen dijelaskan oleh variabel lain diluar model yang dibentuk.

\section{Pengaruh Langsung}

Analisis pengaruh langsung dan tidak langsung maupun pengaruh total dapat menjelaskan hubungan antar variabel. Pengaruh tidak langsung ditujukan oleh koefisien semua anak panah dengan satu ujung, sebaliknya pengaruh tidak langsung terjadi melalui peran satu atau beberapa variabel antara. Untuk mengetahui pengaruh langsung antarvariabel konstruk dapat dilihat dari hasil olahan data dengan nilai path coefficients yang ditampilkan pada Tabel 3. 
Tabel 3

Path Coefficient

\begin{tabular}{ccccl}
\hline $\begin{array}{c}\text { Hubungan } \\
\text { Variabel }\end{array}$ & $\begin{array}{c}\text { Coefficient } \\
\text { Standar }\end{array}$ & $\begin{array}{c}\text { Standar } \\
\text { Error }\end{array}$ & P-value & \multicolumn{1}{c}{ Keterangan } \\
\hline X1 -> Y1 & 0,204 & 7,638 & 0,029 & Signifikan \\
X2 -> Y1 & 0,749 & 4,237 & 0,001 & Signifikan \\
X3 -> Y1 & $-0,016$ & 31,880 & 0,865 & NonSignifikan \\
X4 -> Y1 & $-0,235$ & 3,870 & 0,306 & NonSignifikan \\
X5 -> Y1 & 0,280 & 18,417 & 0,004 & Signifikan \\
X6 -> Y1 & $-0,353$ & 2,880 & 0,002 & Signifikan \\
X1 -> Y2 & 0,311 & 0,018 & 0,000 & Signifikan \\
X2 -> Y2 & 0,441 & 0,010 & 0,001 & Signifikan \\
X3 -> Y2 & 0,214 & 0,073 & 0,000 & Signifikan \\
X4 -> Y2 & 0,140 & 0,009 & 0,285 & NonSignifikan \\
X5 -> Y2 & 0,151 & 0,044 & 0,008 & Signifikan \\
X6 -> Y2 & 0,300 & 0,007 & 0,000 & Signifikan \\
Y1 -> Y2 & 0,355 & 0,000 & 0,000 & Signifikan \\
\hline
\end{tabular}

Sumber : Data Penelitian,2017.

Berdasarkan Tabel 3 dapat dijelaskan bahwa tingkat pendidikan berpengaruh positif dan signifikan terhadap jarak migrasi yang berarti hipotesis diterima. Hal ini ditunjukkan dengan koefisien path sebesar 0,204 dan tingkat signifikan kurang dari 0,05 yaitu dengan nilai P-value 0,029. Umur berpengaruh positif dan signifikan terhadap jarak migrasi yang berarti bahwa hipotesis diterima. Hal ini ditunjukkan dengan koefisien path sebesar 0,749 dengan tingkat signifikansi kurang dari 0,05 yaitu dengan P-value sebesar 0,001.

Etnis Bali memiliki jarak migrasi lebih dekat dibandingkan dengan Etnis nonBali yang berarti hipotesis ditolak. Hal ini ditunjukkan dengan koefisien path sebesar -0,016 dan tingkat signifikansi lebih besar dari 0,05 dengan nilai P-value sebesar 0,865. Lama usia perkawinan berpengaruh negatif dan tidak signifikan terhadap jarak 
migrasi yang berarti hipotesis ditolak. Hal ini ditunjukkan dengan koefisien path sebesar -0,235 dan tingkat signifikansi lebih besar dari 0,05 dengan nilai P-value sebesar 0,306 .

Jumlah tanggungan keluarga berpengaruh positif dan signifikan terhadap jarak migrasi yang berarti hipotesis diterima. Hal ini dapat ditunjukkan dengan nilai koefisien path sebesar 0,280 dan tingkat signifikansi lebih kecil dari 0,05 dengan nilai P-value sebesar 0,004. Lama migrasi berpengaruh negatif dan signifikan terhadap jarak migrasi yang berarti hipotesis ditolak. Hal ini dapat dilihat dari nilai koefisien path sebesar -0,353 dan tingkat signifikansi lebih kecil dari 0,05 dengan nilai P-value sebesar 0,002 .

Tingkat pendidikan berpengaruh positif dan signifikan terhadap tingkat pendapatan yang berarti hipotesis diterima. Hal ini dapat dilihat dari nilai koefisien path sebesar 0,311 dan tingkat signifikansi lebih kecil dari 0,05 dengan nilai P-value sebesar 0,000 . Umur berpengaruh positif dan signifikan terhadap tingkat pendapatan yang berarti hipotesis diterima, dapat dilihat dari nilai koefisien path sebesar 0,441 dan tingkat signifikansi dibawah 0,05 dengan nilai P-value sebesar 0,001. Hal ini berarti semakin tua usia seseorang maka pendapatan akan semakin tinggi pula.

Etnis Bali memiliki pendapatan lebih tinggi dibandingkan etnis non-Bali hal ini berarti hipotesis diterima. Hal ini dapat dilihat dari koefisien path sebesar 0,214 yang berarti pendapatan etnis Bali lebih besar 21,4 juta rupian dari etnis non-bali, dengan tingkat signifikansi dibawah 0,05 dan nilai P-value sebesar 0,000. Lama usia perkawinan berpengaruh positif dan tidak signifikan terhadap tingkat pendapatan 
yang berarti hipotesis ditolak. Hal ini dapat dilihat dari nilai koefisien path sebesar 0,140, dan tingkat signifikansi lebih besar dari 0,05 dengan nilai P-value sebesar 0,285 .

Jumlah tanggungan berpengaruh positif dan signifikan terhadap tingkat pendapatan yang berarti hipotesis diterima. Hasil penelitian menunjukkan nilai koefisien path sebesar 0,151 , dan tingkat signifikansi dibawah 0,05 dengan nilai Pvalue sebesar 0,008. Lama migrasi berpengaruh positif dan signifikan terhadap tingkat pendapatan yang berarti hipotesis diterima. Hal ini dapat dilihat dari nilai koefisien path sebesar 0,300 dan tingkat signifikansi lebih kecil dari 0,05 dengan nilai P-value sebesar 0,000. Jarak migrasi berpengaruh positif dan signifikan terhadap tingkat pendapatan yang berarti hipotesis diterima. Dilihat dari nilai koefisien path sebesar 0,355 dengan tingkat signifikansi dibawah 0,05 dan nilai P-value sebesar 0,000 .

Gambar 3 mendeskripsikan bahwa variabel tingkat pendidikan, umur, etnis, lama usia perkawinan, jumlah tanggungan, lama migrasi dan jarak migrasi serta tingkat pendapatan dapat dibuat diagram jalur. Dalam diagram jalur menunjukkan variabel yang mempunyai pengaruh terbesar terhadap jarak migrasi adalah umur dengan koefisien jalur sebesar 0,749, disusul oleh variabel jumlah tanggungan dengan koefisien jalur sebesar 0,280. Sedangkan variabel yang paling berpengaruh terhadap tingkat pendapatan adalah variabel umur dengan koefisien jalur sebesar 0,441, disusul oleh variabel jarak migrasi dengan koefisien jalur sebesar 0,355. 


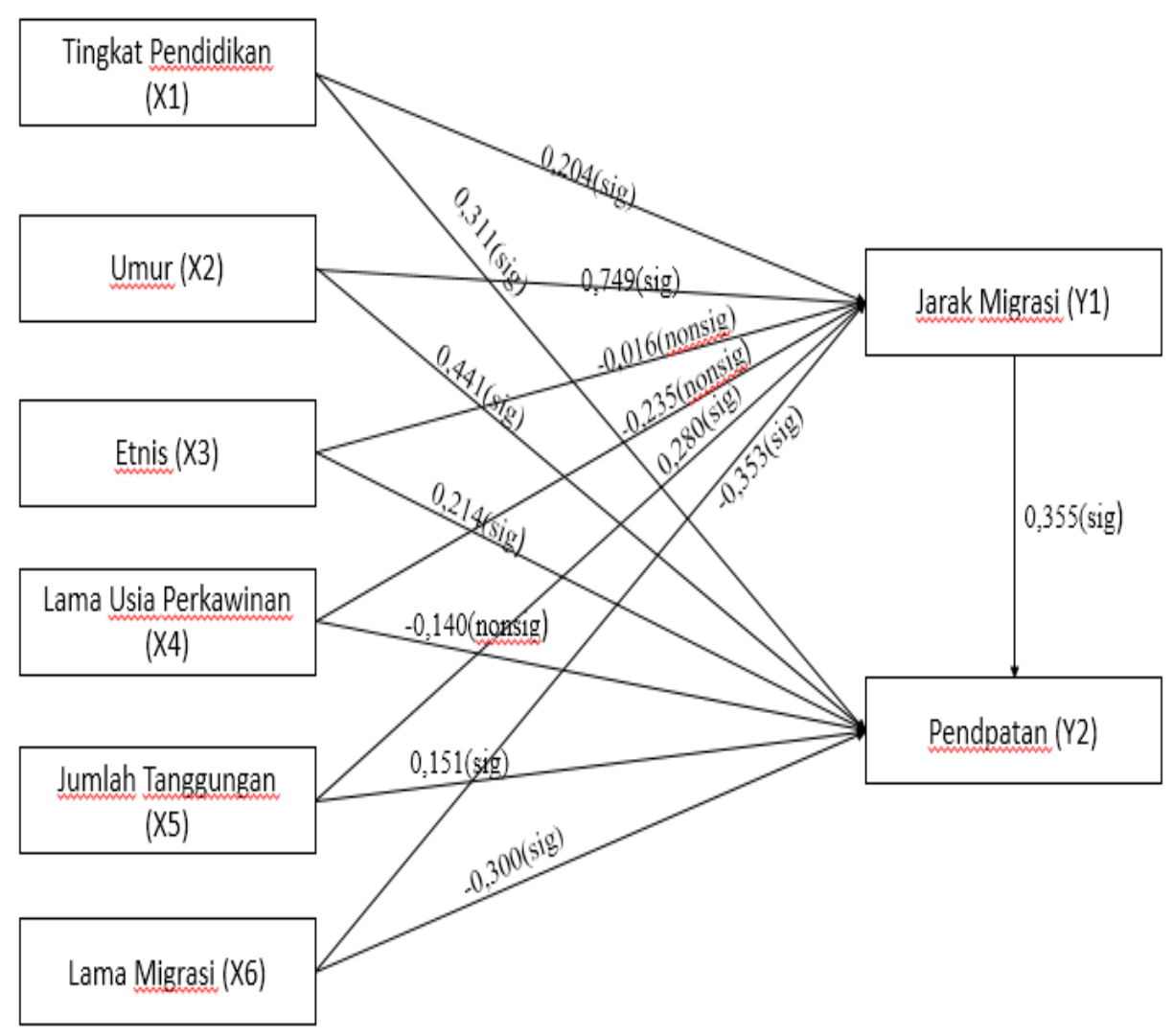

Gambar 3

Diagram Jalur Penelitian

\section{Pengaruh Tidak Langsung}

Hasil pengujian pengaruh tidak langsung antara variabel tingkat pendidikan,umur, etnis, lama usia perkawinan, jumlah tanggungan, lama migrasi terhadap tingkat pendapatan dengan mediasi jarak migrasi secara parsial dapat dilihat pada Tabel 4.

Tabel 4

\section{Hasil Uji Mediasi Secara Parsial}

\begin{tabular}{cccccc}
\hline Variabel & Variabel & Variabel & $\begin{array}{c}\text { Probabilitas } \\
\text { terhadap }\end{array}$ & $\begin{array}{c}\text { Probabilitas } \\
\text { terhadap }\end{array}$ & Ket \\
Eksogen & Mediasi & Endogen & Variabel & Variabel & \\
\hline
\end{tabular}




\begin{tabular}{lllccc} 
& & & Mediasi & Endogen & \\
\hline Pendidikan & $\begin{array}{l}\text { Jarak } \\
\text { Migrasi }\end{array}$ & Pendapatan & 0,029 & 0,000 & Sig \\
Umur & $\begin{array}{l}\text { Jarak } \\
\text { Migrasi }\end{array}$ & Pendapatan & 0,001 & 0,001 & Sig \\
Etnis & $\begin{array}{l}\text { Jarak } \\
\text { Migrasi }\end{array}$ & Pendapatan & 0,865 & 0,000 & Nonsig \\
Lama & $\begin{array}{l}\text { Jarak } \\
\text { Perkawinan }\end{array}$ & $\begin{array}{l}\text { Migrasi } \\
\text { Jumlah }\end{array}$ & Jarak \\
Tanggungan & Migrasi & Pendapatan & 0,306 & 0,285 & Nonsig \\
$\begin{array}{l}\text { Lama } \\
\text { Migrasi }\end{array}$ & $\begin{array}{l}\text { Jarak } \\
\text { Migrasi }\end{array}$ & Pendapatan & 0,004 & 0,008 & Sig \\
\hline Sumber: Datan & Penelian & 0,002 & 0,000 & Sig \\
\hline
\end{tabular}

Sumber : Data Penelitian,2017

Berdasarkan Tabel 4 menunjukkan bahwa secara individu variabel X1 (tingkat pendidikan) terhadap jarak migrasi memberikan nilai koefisien sebesar 16,961 dengan tingkat signifikansi sebesar 0,029 dibawah alpa 0,05. Variabel X1 (tingkat pendidikan) terhadap tingkat pendapatan memberikan nilai koefisien sebesar 0,105 dengan tingkat signifikansi sebesar 0,000 dibawah alpa 0,05. Kedua variabel ini dapat disimpulkan berpengaruh terhadap tingkat pendapatan. Hasil ini menunjukkan bahwa secara parsial variabel jarak migrasi memediasi pengaruh variabel tingkat pendidikan terhadap tingkat pendapatan pedagang migran sektor informal di Kota Denpasar, hal ini berarti hipotesis diterima.

Variabel X2 (umur) terhadap jarak migrasi memberikan nilai koefisien sebesar 14,597 dengan tingkat signifikansi sebesar 0,001 dibawah alpa 0,05. Variabel X2 (umur) terhadap tingkat pendapatan memberi nilai koefisien sebesar 0,035 dengan tingkat signifikansi sebesar 0,001 dibawah alpa 0,05. Kedua variabel ini dapat disimpulkan berpengaruh terhadap tingkat pendapatan. Hasil ini menunjukkan bahwa 
secara parsial variabel jarak migrasi memediasi pengaruh variabel umur terhadap pendapatan pedagang migran sektor informal di Kota Denpasar, hal ini berarti hipotesis diterima.

Variabel X3 (etnis) terhadap jarak migrasi memberikan nilai koefisien sebersar -5,439 dengan tingkat signifikansi sebesar 0,865 diatas alpa 0,05. Variabel X3 (etnis) terhadap tingkat pendapatan memberi nilai koefisien sebesar 0,299 dengan tingkat signifikansi 0,000 dibawah 0,05 . Variabel etnis tidak berpengaruh terhadap jarak migrasi dengan tingkat signifikansi diatas alpa 0,05. Hasil ini menunjukkan bahwa secara parsial variabel jarak migrasi tidak memediasi pengaruh variabel etnis terhadap tingkat pendapatan pedagang migran sektor informal di Kota Denpasar, hal ini berarti hipotesis ditolak.

Variabel X4 (lama usia perkawinan) terhadap jarak migrasi memberikan nilai koefisien -3,984 dengan tingkat signifikansi sebesar 0,306 lebih besar dari alpa 0,05. Variabel X4 (lama usia perkawinan) terhadap tingkat pendapatan memberikan nilai koefisien sebesar -0,010 dengan tingkat signifikansi sebesar 0,285 diatas alpa 0,05. Kedua variabel ini menunjukkan alpa yang lebih besar dari 0,05. Hasil ini menunjukkan bahwa secara parsial variabel jarak migrasi tidak memediasi pengaruh variabel lama usia perkawinan terhadap tingkat pendapatan pedagang migran sektor informal di Kota Denpasar, hal ini berarti hipotesis ditolak.

Variabel X5 (jumlah tanggungan) terhadap jarak migrasi memberikan nilai koefisien sebesar 55,306 dengan tingkat signifikansi 0,004 lebih kecil dari alpa 0,05. Variabel X5 (jumlah tanggungan) terhadap tingkat pendapatan menunjukkan nilai 
koefisien sebesar 0,121 dengan tingkat signifikansi 0,008 lebih kecil dari alpa 0,005. Kedua variabel ini dapat disimpulkan berpengaruh terhadap tingkat pendapatan. Hasil ini menunjukkan bahwa secara parsial variabel jarak migrasi memediasi pengaruh variabel jumlah tanggungan terhadap tingkat pendapatan pedagang migran sektor informal di Kota Denpasar, hal ini berarti hipotesis diterima.

Variabel X6 (lama migrasi) terhadap jarak migrasi memberikan nilai koefisien sebesar -9,416 dengan tingkat signifikan 0,002 lebih kecil dari alpa 0,05. Variabel X6 (lama migrasi) terhadap tingkat pendapatan menunjukkan nilai koefisien sebesar 0,032 dengan tingkat signifikansi 0,000 lebih kecil dari alpa 0,000. Kedua variabel ini dapat disimpulkan berpengaruh terhadap tingkat pendapatan. Hasil ini menunjukkan bahwa secara parsial variabel jarak migrasi memediasi pengaruh variabel lama migrasi terhadap tingkat pendapatan pedagang migran sektor informal di Kota Denpasar, hal ini berarti hipotesis diterima.

\section{Pengaruh Langsung, Pengaruh Tidak Langsung, dan Pengaruh Total}

Koefisien pada Tabel 5 merupakan koefisien jalur pengaruh langsung sedangkan ringkasan pengaruh langsung, tidak langsung, dan pengaruh total dapat dilihat pada Tabel 5 .

Tabel 5

Ringkasan Pengaruh Langsung, Pengaruh Tidak Langsung, Dan Pengaruh Total antar Variabel Penelitian

\begin{tabular}{ccccccc}
\hline Konstruk & \multicolumn{6}{c}{ Konstruk Dependen } \\
\cline { 2 - 7 } Independen & \multicolumn{5}{c}{ Y1 } & \multicolumn{3}{c}{ Y2 } \\
\cline { 2 - 7 } & PL & PTL & PT & PL & PTL & PT \\
\hline X1 & 0,204 & & 0,204 & 0,311 & 0,072 & 0,383
\end{tabular}




$\begin{array}{lccccc}\text { X2 } & 0,749 & 0,749 & 0,441 & 0,266 & 0,707 \\ \text { X3 } & -0,016^{*} & -0,016 & 0,214^{*} & 0,005^{*} & 0,209 \\ \text { X4 } & -0,235^{*} & -0,235 & -0,140^{*} & 0,083^{*} & \\ \text { X5 } & 0,280 & 0,280 & 0,151 & 0,099 & 0,250 \\ \text { X6 } & -0,353 & -0,353 & -0,300 & 0,125 & \\ & & & 0,355 & & \\ \end{array}$

Sumber : data penelitian,2017.

Berdasarkan Tabel 5 dijelaskan bahwa secara langsung variabel umur memiliki pengaruh dominan terhadap jarak migrasi dengan nilai sebesar 0,749 , dan secara langsung variabel umur juga memiliki pangaruh paling dominan terhadap tingkat pendapatan dengan nilai sebesar 0,441. Secara tidak langsung variabel umur melalui jarak migrasi memiliki pengaruh dominan terhadap tingkat pendapatan dengan nilai sebesar 0,266 , dan secara total nilai terbesar adalah variabel umur sebesar 0,707 .

\section{Pembahasan Hasil Penelitian}

Berdasarkan hasil analisis menunjukkan tingkat pendidikan berpengaruh positif dan signifikan terhadap jarak migrasi pedagang wanita migran sektor informal di Kota Denpasar hal ini berarti hipotesis penelitian diterima. Semakin tinggi tingkat pendidikan, maka akan semakin tinggi pula probabilitas perempuan dalam menempuh jarak migrasi. Umur berpengaruh positif dan signifikan terhadap jarak migrasi pedagang migran wanita sektor informal di Kota Denpasar, hal ini berarti hipotesis penelitian diterima. Semakin dewasa umur responden maka jarak migrasi akan semakin jauh. Tidak ada batasan umur untuk masuk dalam kegiatan usaha informal, 
karena sektor ini mengutamakan keterampilan dan kemampuan fisik yang baik untuk bekerja (Menon, 2011).

Etnis berpengaruh negatif dan tidak signifikan terhadap jarak migrasi pegadang wanita migran sektor informal di Kota Denpasar. Hasil menunjukkan bahwa Etnis Bali memiliki jarak yang lebih dekat dibandingkan dengan Etnis nonBali. Etnis Bali masih melakukan migrasi di sekitaran Provinsi yang ada di Bali. Lama usia perkawinan berpengaruh negatif tidak signifikan terhadap jarak migrasi pedagang wanita migran sektor informal di Kota Denpasar, hal ini berarti hipotesis ditolak. Hasil ini menunjukkan bahwa lama usia perkawinan seseorang tidak menentukan sejauh mana seseorang akan melakukan migrasi. Responden yang berstatus menikah memiliki probabilitas lebih rendah dalam melakukan migrasi dibandingkan dengan status lainnya (Isserman, 1985).

Jumlah tanggungan berpengaruh positif dan signifikan terhadap jarak migrasi pedagang wanita migran sektor informal di Kota Denpasar, yang artinya hipotesis dapat diterima. Hal ini menunjukkan semakin banyak jumlah tanggungan semakin jauh jarak tempuh migrasi responden (Hasudungan dkk, 2013). Jumlah tanggungan keluarga dapat menjadi alasan penduduk melakukan migrasi. Lama migrasi berpengaruh negatif dan signifikan terhadap jarak migrasi pedagang wanita migran sektor informal di Kota Denpasar, yang berarti hipotesis ditolak karena memiliki arah yang negatif. Hal ini berarti semakin lama seseorang melakukan migrasi maka jarak akan semakin dekat (Wajdi, 2010). 
Jarak migrasi berpengaruh negatif dan signifikan terhadap tingkat pendapatan pedagang wanita migran sektor informal di Kota Denpasar, yang berarti hipotesis ditolak karena arahnya negatif. Hal ini berarti semakin dekat jarak migrasi yang ditempuh pendapatan yang diterima akan semakin tinggi. Terjadinya perkembangan di kawasan perkotaan yang memiliki variasi lapangan pekerjaan lebih banyak menyebabkan adanya interaksi antara kota dengan kawasan pinggiran di sekitarnya (Christauskas and Miseviciene, 2012).

Berdasarkan hasil analisis menunjukkan bahwa jarak migrasi memediasi secara parsial pengaruh tingkat pendidikan terhadap pendapatan pedagang wanita migran sektor informal di Kota Denpasar, sehingga dapat diartikan bahwa tingkat pendidikan berpengaruh tidak langsung terhadap tingkat pendapatan. Hal ini sesuai dengan teori modal manusia yang dikemukakan oleh Becker,1964 dan Mincer 1974 yang berteori bahwa adanya hubungan positif antara pendapatan dan investasi dalam modal manusia melalui pencapaian pendidikan.

Jarak migrasi memediasi pengaruh umur terhadap tingkat pendapatan pedagang wanita migran sektor informal di Kota Denpasar. Hal ini berarti umur berpengaruh tidak langsung terhadap tingkat pendapatan wanita migran sektor informal di Kota Denpasar melalui jarak migrasi. Umur merupakan salah satu faktor yang mempengaruhi pendapatan (Cahyono, 1998). Umur produktif berkisar antara 15-64 tahun yang merupakan umur ideal bagi para pekerja pada sektor informal yang berkembang (Dwiandana, 2013). 
Jarak migrasi tidak memediasi pengaruh etnis terhadap tingkat pendapatan wanita migran sektor informal di Kota Denpasar. Hal ini diartikan bahwa etnis tidak berpengaruh terhadap tingkat pendapatan yang diperoleh pedagang migran wanita sektor informal di Kota Denpasar. Hasil penelitian menunjukkan bahwa etnis Bali tidak memiliki pendapatan lebih tinggi dibandingkan dengan etnis Non-Bali. Dari hasil penelitian etnis Bali memiliki tidak pendapatan yang lebih tinggi dengan Etnis Non-Bali. Faktor kebutuhan menjadi salah satu yang menentukan pola belanja konsumen. Bagi orang Bali mereka lebih cenderung berbelanja pada Pedagang dengan Etnis Bali. Penelitian ini didukung oleh penelitian Thamrin (2012) yang menunjukkan bahwa etnis seseorang tidak berpengaruh terhadap tingkat pendapatannya.

Jarak migrasi tidak memediasi pengaruh lama usia perkawinan terhadap tingkat pendapatan wanita migran sektor informal di Kota Denpasar. Hal ini diartikan bahwa lama usia perkawinan tidak berpengaruh terhadap tingkat pendapatan pedagang migran wanita sektor informal di kota Denpasar. Pekerja yang berstatus pernah kawin atau berkeluarga menerima pendapatan atau upah yang sama dari pekerja yang berstatus tidak kawin. Hal ini disebabkan, pekerja yang baru menikah dengan pekerja yang usia perkawinannya cukup lama tetapi tidak memiliki keterampilan pada bidang tertentu yang dituntut dalam pekerjaannnya akan memperoleh upah rata-rata atau sesuai dengan upah minimum (Sanis, 2010).

Jarak migrasi memediasi pengaruh jumlah tanggungan terhadap tingkat pendapatan wanita migran sektor informal di Kota Denpasar, maka dapat diartikan 
bahwa jumlah tanggungan berpengaruh positif dan signifikan terhadap tingkat pendapatan pedagang wanita migran sektor informal di Kota Denpasar. Hubungan jumlah tanggungan keluarga dengan pendapatan dijelaskan oleh Simanjuntak (2001:201), semakin banyaknya jumlah anggota keluarga yang ikut makan dan hidup maka memaksa untuk mencari tambahan pendapatan dari tenaga kerja yang bersangkutan.

Jarak migrasi memediasi pengaruh lama migrasi terhadap tingkat pendapatan wanita pedagang migran sektor informal di Kota Denpasar. Hal ini berarti bahwa lama migrasi berpengaruh negatif dan signifikan terhadap tingkat pendapatan. Seorang migran yang baru pergi ke kota memiliki keperluan yang banyak untuk memenuhi kebutuhan mereka hidup di daerah tujuan sehingga akan memacu seseorang untuk bekerja lebih giat bekerja sehingga otomatis pendapatan akan semakin tinggi (Indrareni, 2013). Tanda negatif pada koefisien menunjukkan bahwa semakin lama responden melakukan migrasi di Kota Denpasar, maka pendapatan akan semakin berkurang, maksudnya disini keperluan-keperluan yang dibutuhkan akan semakin banyak sehingga pendapatan harus semakin tinggi untuk memenuhi kebutuhan tersebut yang mengakibatkan pendapatan yang akan diperoleh semakin berkurang untuk memenuhi kebutuhan tersebut (Chen, 2012)..

\section{KESIMPULAN DAN SARAN}

Tingkat pendidikan, umur, jumlah tanggungan dan lama migrasi berpengaruh signifikan terhadap jarak migrasi. Lama usia perkawinan berpengaruh negatif dan tidak signifikan terhadap jarak migrasi. Tingkat pendidikan, umur, jumlah 
tanggungan, lama migrasi dan jarak migrasi berpengaruh signifikan terhadap tingkat pendapatan pedagang. Lama usia perkawinan berpengaruh negatif dan tidak signifikan terhadap pendapatan pedagang. Variabel etnis Bali memiliki pendapatan lebih tinggi dibandingkan dengan etnis non-Bali. Jarak migrasi tidak memediasi pengaruh etnis dan lama usia perkawinan terhadap pendapatan. Pengembangan sektor informal di Kota Denpasar yaitu dengan memberikan pinjaman bagi pelaku usaha di sektor informal.

Pemerintah harus mengadakan kebijakan yang pro rakyat golongan menengah ke bawah khususnya pada sektor informal agar dapat memperkecil kesenjangan ekonomi antara sektor formal dan sektor informal, karena pada kenyataannya, sektor informal mampu menyerap jumlah karena pendapatan yang mereka terima pun cukup dapat digunakan untuk memenuhi kebutuhan sehari-hari, sehingga pengembangan sektor informal sangat penting dilakukan dalam upaya menyerap pengangguran dan upaya pengentasan kemiskinan khususnya di Kota Denpasar.

\section{REFERENSI}

Badan Pusat Statistik, 2008. Berita Resmi Statistik : Keadaan Ketenagakerjaan Provinsi Tahun 2008, Denpasar.

Becker, G.S,1964. Human Capital : a Theoretical And Empirical Analysis With Special Reference to Education. Journal. New York : Coloumbia University Press.

Boserup, Ester. 1984. The Role of Women In Economic Development. Journal Volume 7, no2. The University of Chicago. London.

Chiswick, B. R. and T. J. Hatton. (2003). International Migration and The Integration of Labor Markets, in M. D. Bordo, A. M. Taylor, and J. G. Williamson (eds.), Globalization in historical Perspective. Journal Press, pp. 65-120. Chicago : University of Chicago. 
Chistauskas, Ceslovas. 2012. Cloud- Computing Based Accounting For Small To Medium Sized Business. Journal Inzenerine Ekonomika-engineering economics. Vol 23(1), pp 14-21. Kaunas University of Technology.

Chen, Ying. (2012). Research on Risk of Supply Chain Finance of Small And Medium Sized Enterpries Based on Fuzzy Ordinal Regression Support Vector Machine. Journal International Of Business and Management vol 7, No 8. Shanghai. China.

Dwiandana, Putri. 2013. Pengaruh Umur, Pendidikan, Pekerjaan Terhadap Pendapatan Rumah Tanga Miskin Di Desa Bebandem. E-Jurnal Ekonomi Pembangunan Volume 2, No 4, April 2013. Universitas Udayana. Denpasar.

Forsman, Helena. 2011. Innovation And Business Performance In Small EnterPrises, An Enterprises-Level Analysis. Journal Of Innovation Management Vol. 15, No 3, pp. 641-655. The University of Winchester, Winchester Business School.

Guntoro, Dibyo Waskito. 2016. Analisi Faktor-Faktor yang Mempengaruhi Penduduk Melakukan Migrasi Internal di Indonesia. Jurnal. Fakultas Ekonomi Universitas Negeri Yogyakarta.

Gugler, Josef. (1989). Women Stay on Farm No More, Changing Pattern Of RuralUrban Migration In Sub Sahara Africa. Journal of Modern African Studies, Vol 27, No. 2, pp. 347-352. Africa.

Hasudungan, Kaisar dan Herniwati. 2013. Analisis Pengaruh Pendapatan, Pendidikan, Pekerjaan Daerah Asal, Jumlah Tanggungan dan Status Perkawinan Terhadap Keputusan Migrasi Sirkuler Di kota Semarang. Jurnal vol 2, No 3, Tahun 2013, Hal 1-10. Fakultas Ekonomi Universitas Dipobegoro.

Indrawati, Surachmi, 2009. Perempuan di Sektor Informal (Studi kasus Pedagang Sayur Sekitar Pasar Terong Makassar). Jurnal. Universitas Sawerigading, Makassar.

Indrareni, Anindita. 2013. Pengaruh Pergerakan Pekerja Commuter Terhadap Pola Konsumsi di Kecamatan Kaliwungu. Jurnal Teknik PWK Volume 2 No4,2013. Fakultas Teknik Universitas Diponegoro.

Isserman, A.M, D.A. Plane, P.A. Rogersen and P.M. Beaumont. (1985). Forecasting Interstate Migration With Limited Data: A Demographic-Economic 
Approach. Journal, Volume 80, No 390. The American Statistical Association. America.

Keban, Yeremias T. 1994. Studi Niat Bermigrasi Di Tiga Kota : Determinan dan Intervensi Kebijakan. Jurnal Prisma, No. 7 Juli 1994.

Lily, Julian, et all. 2006. A Gender - Sensitive Study Of Mcclelland's Needa, Stress And Turnover Intent With Work - Family Conflict. Journal Women in Managent Review Volume 21 no. 8 pp. 662-680. Mcclelland.

Lokhande, Madhavi. 2011. Financial Inclusion : Options for Micro, Small and Medium Enterprises. Journal Volume IX no II. Fakulty of Finance and Academics Welingkar Institute Of Management Development and Research. Bangalore. India.

Mantra,I.B,1992., Mobilitas Penduduk Sirkuler Dari Desa ke Kota di Indonesia , Pusat Penelitian Kependudukan Universitas Gajah Mada.

2003. Demografi Umum. Edisi ke-2. Yogyakarta: Pustaka Belajar. CV. Mandara Maju.

Marhaeni, Anak Agung Istri Ngurah, 2008. Perkembangan Studi Perempuan, Kritik dan Gagasan Sebuah Perspektif Untuk studi Gender Ke Depan. Jurnal. Denpasar. Fakultas Ekonomi Universitas Udayana.

1992. Alokasi Waktu Pekerja Wanita Pada Industri Garmen di Daerah Sanur Kecamatan Denpasar Selatan. Jurnal Berkala Volume I tahun 1992. Penelitian Pasca Sarjana Universitas Gajah Mada, Yogyakarta.

Menon,Vanaja. 2012. Women Participation : Paradoxes in Management of Small Scale Industries : Urban - Rural Disparities. Journal Volume 7 no 1. International Journal Of Business and Management. Departement of Marketing, New York Institute of Technology.

Miseviciene, Regina. 2012. Cloud- Computing Based Accounting For Small To Medium Sized Business. Journal Inzenerine Ekonomika-engineering economics. Vol 23(1), pp 14-21. Kaunas University of Technology.

Ramarao, Ravulaparthy. 2015. Competitiveness of India's Micro and Small Enterprises Throught Funcional Competencies: Role in Nation's 
Development. Journal Vikalpa No 1 Volume 37 Tahun 2012. Indian Institute of Management. Ahmedabad.

Sanis, S., 2010. Analisis Pengaruh Upah, Lama Migrasi, Umur, dan Tingkat Pendidikan Terhadap Minat Migrasi Sirkuker Penduduk Salatiga ke Kota Semarang. Jurnal. FAkultas Ekonomi Universitas Diponegoro. Semarang.

Subair, Kola. 2011. Foreign Direct Investment And Development Of Small And Medium Scale Enterprises In Nigeria. African Journal ofconimics, Finance and Banking Research Vol \&. No 7. Kwara State University. Malete.

Suyana Utama Made, 2010. Modul Metode Kuantitatif. Diktat Kuliah Magister Ilmu Ekonomi Universitas Udayana.

Suryaningsih. 2006. Pola Migrasi di Provinsi Sumatera Utara dan Kaitannya Dengan Hukum dan Kependudukan. Jurnal Ilmiah. Fakultas Hukum Universitas Sumatera Utara.

Tjiptoherijanto, Priyono. (2000). Mobilitas Penduduk dan Pembangunan Ekonomi, Makalah disampaikan dalam Simposium Dua Hari Kantor Menteri Negara Transmigrasi dan Kependudukan/BAKMP, Jakarta 25-26 Mei.

Todaro, Michael P. 2000. Pembangunan Ekonomi. Terjemahan. Haris Munandar. Edisi 5, Cetakan 1. Jakarta : Bumi aksara.

Temel, Serdal. 2011. Innovation And Business Performance In Small EnterPrises, An Enterprises-Level Analysis. Journal Of Innovation Management Vol. 15, No 3, pp. 641-655. The University of Winchester, Winchester Business School.

Widarti, Diah. 1984. Analisis Ketenagakerjaan di Indonesia Berdasarkan Data Sensus Penduduk Tahun 1971 dan 1980, dalam Chris Manning dan Mikhael Papayung, Analisis Ketenagakerjaan di Indonesia Berdasarkan Data Sensus Penduduk 1971 dan 1980. Jakarta: Biro Pusat Statistik, 57-132.

Wajdi, M. Nashrul. (2010). Migrasi Antar Pulau Indonesia : Analisis Model Skedul Migrasi dan Model Gravitasi Hybrida. Jurnal. Program Studi Kajian Kependudukan dan Ketenagakerjaan Program Pascasarjana Universitas Indonesia. Depok. 